\title{
Saudação aos Professores Eméritos (*)
}

\author{
Spencer Vampré
}

Quis a Congregação desta Faculdade que, neste jubiloso dia Onze de Agosto, se conferissem a cinco de seus notaveis Mestres os diplomas de professores eméritos, como que a vinculá-los ainda, e mais fortemente, às nossas tradições, aos nossos trabalhos quotidianos, e aos nossos destinos.

Não há, senhores, mais alta e mais honrosa investidura, do que, ao cabo de uma nobre carreira, toda votada ao ensino e à ciência do direito, receberdes aqui, como supremo gaļardão de vossa vida universitária, o público e solene reconhecimento de quanto fizestes pela mocidade e pela Pátria.

Nem há, em todas as honrarias da República, cargo de maior preeminência, função de mais delicada e mais larga contextura, missão de mais viva responsabilidade, do que a que vos permite abrir à cultura juvenil os horizontes do espirito e gravar no cristal da alma dos moços as primeiras lições inesqueciveis de amor à ordem jurídica, de respeito aos direitos do cidadão, de justiça social e de justiça individual, estreitamente irmanadas ao serviço do Brasil.

Bemaventurados os que podem sentir, cada manhã, nestas veneraveis arcadas, o chilrear das andorinhas inquietas, que aqui pousam por um momento, para desferirem em se-

(*) Discurso pronunciado, a 11 de agosto de 1942 , em nome da. Congregação da Faculdade de Direito, por ocasião da entrega dos diplomas de professores aos antigos lentes drs. José Ulpiano Pinto de Sousa, Reynaldo Porchat, Candido Nazianzeno Nogueira da Mota, João Braz de Oliveira Arruda e José Manoel de Azevedo Marques. 
guida o seu vôo triunfal em todos os quadrantes do País; bemaventurados os que podem fazer palpitar o coração dos moços, ao toque das inspirações da ciência, e podem devassar aos seus espíritos sedentos as soluções das grandes doutrinas.

Casa da Mocidade, aqui repercutem todos os movimentos do pensamento nacional; Casa da Esperança, aqui se aninham os melhores anceios de nossa grei; casa da Saudade, aqui permanecem vivos os que já partiram para a grande viagem donde ninguem volta; Casa da Pátria, aqui estão abertos e patentes os seus luminosos portais, a quantos sintam no coração a chama do idealismo, a quantos queiram marchar, unidos e ovantes, para a construção do futuro.

O que queremos significar nesta solenidade é que não nos apartamos dos grandes Mestres, a quem a lei afastou da docência efetiva, mas a quem a nossa admiração elevou à dignidade, não já de Mestres dos alunos, mas de Mestres dos Mestres.

A cada um de vos quizemos honrar, por vossa longa vida intelectual, por denodado e incansavel esforço, por larga e alta mésse de realizações do ensino, - vida, esforço e realizações, que se não podem resumir nestas singelas palavras, mas que se acham estampados na memória de todos nós e se integraram de há muito nas tradições desta Academia.

Em Reynaldo Porchat, revivemos as eloquentes lições de direito romano, onde a emoção das evocações históricas emparelhava, a cada momento, com a profundidade dos conceitos doutrinários; e ainda nos ressoam aos ouvidos as vozes com que levantava do túmulo, e repassava, ante os nossos olhos atentos, a figura refulgente dos grandes jurisconsultos clássicos.

Em José Ulpiano, recordamos o expositor conciso e claro, elementar e ao mesmo tempo profundo, que tomava os sumos problemas do direito civil e os destrinçava de complicações teóricas aos nossos espíritos curiosos. 
Em Azevedo Marques, a singelieza e a vivacidade da fórma, a originalidade das doutrinas e a coragem intelectual, lhe assinalaram logar de merecido destaque no direito civil e no processo civil brasileiro.

Em Joño Arruda, admiramos a cultura universal do filósofo erudito e penetrante, ao mesmo tempo curioso e profundo, ensaista e comentador de raros méritos, evocador de reminiscências do fôro e da cátedra, que há-de sempre ser lido com deleite e proveito.

Em Candido Motta, (ai de nós! já não pertence ao mundo dos vivos!) tínhamos um corajoso e tenaz partidário da escola positiva de direito criminal, cujos progressos seguiu atento até o último lampejo, numa laboriosa vida que foi um apostolado de fé doutrinária, de convicções científicas radicadas, exemplo e lustre de uma geração inteira.

Eis aqui, senhores, o que a Congregação da Faculdade de Direito desta Universidade quiz que vos dissesse neste momento, recordando tudo quanto fizestes, e esperando que continueis em vossa gloriosa e fecunda seara.

Assim possamos, por. largos e dilatados anos, celebrar em cada Onze de Agosto, novos serviços e realizações vossas, a bem do Direito e da Pátria. 